\author{
С.О. Шуляков ${ }^{1}$, В.Б. Бзот ${ }^{2}$, С.І. Жилін ${ }^{2}$, Н.В. Шигімага ${ }^{2}$, А.А. Артеменко ${ }^{2}$ \\ ${ }^{1}$ Науково-дослідний иентр ракетних військ і артилерії, Суми \\ ${ }^{2}$ Харківський національний університет Повітряних Сил ім. І. Кожедуба, Харків
}

\title{
ШЛЯХИ УДОСКОНАЛЕННЯ РОЗВІДУВАЛЬНОГО ЗАБЕЗПЕЧЕННЯ БОЙОВОГО ЗАСТОСУВАННЯ РАКЕТНИХ ВІЙСЬК І АРТИЛЕРІЇ
}

\begin{abstract}
В статті розглянута система розвідки, як складова інформаційного забезпечення функціонування автоматизованої системи управління (АСУ) підрозділів ракетних військ і артилерії (РВіА). Проведено аналіз особливостей АСУ польової артилерії Advanced Field Artillery Tactical Data System, шуо є складовою ACУ армійського корпусу Сполучених Штатів Америки та багаторівневої АCУ ADLER II сухопутних військ збройних сил Німеччини. Визначено, щуо можливим иляхом вдосконалення системи розвідувального забезпечення РВіА є організація отримання розвідувальної інформації про об 'єкти противника від усіх органів військового управління тактичної та оперативної розвідки (засобів розвідки), щэо діють у зоні відповідальності (смузі оборони, наступу) угруповання військ.
\end{abstract}

Ключові слова: розвідка, засоби вогневого ураження, розвідувально-вогнева система ракетних військ $i$ артилерії, система бойового управління, розвідувально-вогневий комплекс.

\section{Вступ}

Постановка проблеми. Досвід застосування збройних сил провідних країн світу в локальних конфліктах свідчить, що сучасні бойові дії характеризуються маневреними та динамічними діями частин і підрозділів міжвидових угруповань військ (сил) в операційних районах (зонах). Різноманіття бойових завдань, що вирішуються в ході ведення операцій (бойових дій), висувають підвищені вимоги до сил і засобів розвідки, вимагають спрямування їх дій для своєчасного забезпечення командирів (начальників) актуальною, повною та достовірною розвідувальною інформацією, необхідною для прогнозування дій противника, здійснення заходів концептуального та детального планування, прийняття командирами обгрунтованих і своєчасних рішень щодо вогневого ураження об'єктів противника з метою підвищення ефективності бойового застосування, у тому числі, частин (підрозділів) ракетних військ і артилерії (РВіA).

Основу успішного та ефективного досягнення мети операції (ведення бойових дій) становить своєчасне і ефективне застосування засобів ураження, що безпосередньо пов'язано з результатами розвідувально-інформаційної роботи, в тому числі на основі розвідувальних даних артилерійської розвідки [1] Розвідувально-інформаційна діяльність спрямовується на своєчасне викриття замислу дій противника (з метою виключення його раптових дій), виявлення районів і місць розташування військ (сил), визначення структури та координат потенційних об'єктів ураження з необхідною достовірністю та точністю.
Аналіз досвіду бойових дій на сході України показує, що наявні комплекти розвідки оперативних (оперативно-тактичних) угрупувань військ не дозволяють повною мірою реалізувати потенційні бойові можливості PBiА щодо вогневого ураження об'єктів та угруповань військ (сил) противника [2]. Тому існує нагальна потреба визначення шляхів удосконалення системи розвідувального забезпечення бойового застосування частин та підрозділів PBiА 3 метою створення на їх основі ефективної розвідувально-вогневої системи.

Аналіз останніх досліджень і публікацій. Аналіз проведених досліджень і публікацій [1-9] 3 зазначених питань показує, що сучасний етап розвитку збройних сил провідних у військовому відношенні країн світу характеризується створенням інтегрованої розвідувально-інформаційної підсистеми PBiA, яка орієнтована на застосування всіх структурних елементів (сил і засобів розвідки, інформаційного забезпечення, управління) за єдиним замислом, в єдиному інформаційному просторі для забезпечення оперативного (в масштабі часу, наближеного до реального) реагування на зміни поточної обстановки в районах виконання завдань.

Широке застосування автоматизованих систем управління (АСУ) військами та зброєю оцінюється військовими спеціалістами НАТО як один із найважливіших факторів досягнення військово-технічної переваги над противником. На їх думку, розроблення і прийняття на озброєння сучасних комплексів АСУ значно скорочує час прийняття обгрунтованих i раціональних рішень 3 управління підрозділами i вогневими засобами, що сприяє підвищенню ефек- 
тивності виконання поставлених завдань в умовах суттєвого обмеження часу та 3 найменшою витратою засобів ураження [3].

Метою статті є: розкрити сутність та зміст розвідувального забезпечення бойового застосування РВіА в сучасних операціях (бойових діях);

визначити напрямки вдосконалення системи розвідки з урахуванням подальшого розвитку бойових можливостей засобів вогневого ураження РВіА на підставі досвіду, набутого з'єднаннями, частинами та підрозділами Збройних Сил (ЗС) України при проведенні операції Об'єднаних сил (Антитерористичної операції) на сході нашої держави та з урахуванням досвіду збройних сил провідних країн світу.

\section{Виклад основного матеріалу}

Розвідка, як вид оперативного (бойового) забезпечення операції (бойових дій військових частин, підрозділів РВіА), організується і ведеться постійно, в будь-яких умовах обстановки в мирний і воєнний час з метою виключення раптовості дій противника і своєчасного забезпечення командування повною, достовірною та актуальною розвідувальною інформацією, необхідною для планування застосування військ (сил) та засобів вогневого ураження.

Оскільки РВіА відіграють значну роль у вогневому ураженні противника, то і розвідувальноінформаційна діяльність, яка ведеться в їх інтересах, набуває такого ж важливого значення. На даний час тільки комплексне застосування всіх сил та засобів розвідки оперативного і тактичного рівнів (у тому числі і артилерійської) дозволить реалізувати в повному обсязі бойовий потенціал угрупувань $\mathrm{PBiA}$, оскільки ефективність їх застосування безпосередньо залежить від якості організації та ведення розвідки, а також можливостей іiї сил і засобів щодо добування необхідної розвідувальної інформації [2].

3 метою підвищення ефективності управління військовими формуваннями військово-політичне керівництво провідних країн світу приділяє значну увагу розробленню і розгортанню у військах АСУ військами та зброєю, зокрема у частинах та підрозділах польової артилерії (ПА).

Для реалізації концепції військово-технічної переваги над противником у США була розроблена автоматизована система управління армійського корпусу Army Tactical Command and Control System (ATCCS) (AN/GSC-10) [4]. До іiі складу входить ACУ польової артилерії Advanced Field Artillery Tactical Data System (AFATDS) (рис. 1). AFATDS це багатоцільова тактична інформаційна система ПА на рухомих засобах [4], яка забезпечує автоматизоване прийняття рішень для забезпечення функціонування підсистеми вогневої підтримки, як сухопутних військ і морської піхоти, так і об'єднаних оперативних формувань (міжвидових угруповань) та родів військ (наприклад, застосування корабельної артилерії, координацію ближньої авіаційної підтримки).

Ця повністю інтегрована система управління здійснює:

- єдине комплексне і координоване планування вогневого ураження;

- координацію бойових дій підрозділів артилеpiï;

- управління розвідувальними підрозділами артилерійських частин та засобами радіоелектронної боротьби (РЕБ);

- топогеодезичну прив'язку вогневих позицій (ВП), командно-спостережних пунктів (КСП), постів та позицій артилерійської розвідки (АР) та корегування вогню;

- синхронізацію інформації, що надходить від сил та засобів АР та розвідки інших родів військ, іiі узагальнення й передачу визначеним користувачам;

- управління веденням вогню ПА та мінометів, вогню морської артилерії, реактивних систем залпового вогню (РСЗВ) і керованих ракет при вогневій підтримці військ, ураженні засобів високоточної зброї та артилерії противника, вогневих засобів протиповітряної оборони (ППО);

- оцінювання ефективності вогневого ураження об'єктів (цілей) противника;

- вибір пріоритетних цілей, підбір оптимальної послідовності знищення сил, засобів та об'єктів противника і виключення ведення вогню по власних (дружніх) силах;

- планування та управління переміщенням підрозділів ПА;

- координацію метеорологічного і топогеодезичного забезпечення бойових дій підрозділів ПА;

- розроблення плануючих та розпорядчих документів;

- планування та управління матеріальнотехнічним забезпеченням артилерійських підрозділів;

- виконання всіх оперативних функцій вогневої підтримки, у тому числі автоматизоване розподілення цілей на основі аналізу важливості (пріоритетності) об'єктів вогневого ураження.

Елементи АСУ розгортаються у всіх елементах бойового порядку - від вогневих взводів до штабних підрозділів управління корпусу та дозволяють передавати дані до єдиної бази даних ABCS, а також забезпечують взаємодію з АСУ і системами зброї інших видів збройних сил [5] в операційному районі.

АСУ отримують інформацію про противника від засобів розвідки цілей ПА та інших сил і засобів (видів) розвідки. Також в них вводяться дані про місцеположення своїх військ (координати районів, по яких заборонено ведення вогню), дані засобів 
балістичної підготовки і пристрілювання та інформація про метеорологічну обстановку. На основі цих даних здійснюється планування заходів вогневої підтримки.

У загальному вигляді алгоритм роботи AFATDS можна визначити схемою: викриття противника - аналіз (оцінка) - постановка завдань вогневе ураження - оцінювання результатів ураження цілей.

Існує чотири основні напрямки роботи системи AFATDS [4]:

- збір даних від мобільної радіолокаційної системи ПА дивізії США “Файрфайндер” (Firefinder) контрбатарейних радарів, причому кожний радар дивізіону має інформаційне сполучення зі штабом свого дивізіону для того, щоб контрбатарейний удар наносився якнайшвидше, без залучення в процесі прийняття рішення центру управління бойовими діями (ЦУБД);

- збір даних (fire reqest) від підрозділів артилерійських розвідників (COLT), представників авіації (JTAC), ПАС (FO);

- збір даних від підрозділів радіотехнічної розвідки (РТР) (у кожному штабі від батальйону й вище $\epsilon \mathrm{RW}$ фахівець, відповідальний за уточнення й контроль даних РТР), повітряної видової (іконічної) розвідки (IMINT) та сил і засобів розвідки вищого командування й т.п.;

- формування планів ураження - як артилерійськими засобами, так і планів комплексного ураження (fire plan), при цьому важливе місце займає безпека польотів і оброблення даних трас стрільби та визначення коридорів прольоту авіації.

Таким чином, у загальній архітектурі АСУ AFATDS можна спостерігати розвідувальноінформаційну взаємодію між технічними засобами розвідки і центром управління бойовими діями (ЦУБД) та розвідувально-вогневу взаємодію між засобами розвідки (контрбатарейних радарів (Firefinder)) і засобами вогневого ураження об'єктів противника (артилерійських дивізіонів), що забезпечує створення розвідувально-вогневого комплексу (рис. 1).

Основна ідея полягає в інтеграції всіх сил і засобів у єдиному інформаційному просторі, що дозволяє суттєво збільшити ефективність їх бойового застосування за рахунок синергетичного ефекту [6].

За поглядом командування сухопутних військ (CB) збройних сил Німеччини [7], розвідка - вирішальна умова для планування та управління операцією (бойовими діями) командиром загальновійськового з'єднання, в тому числі і діями артилерійських підрозділів.

Одним з пріоритетних напрямів розвитку СВ 3С Німеччини залишається вдосконалення систем бойового управління військами на основі модерні-

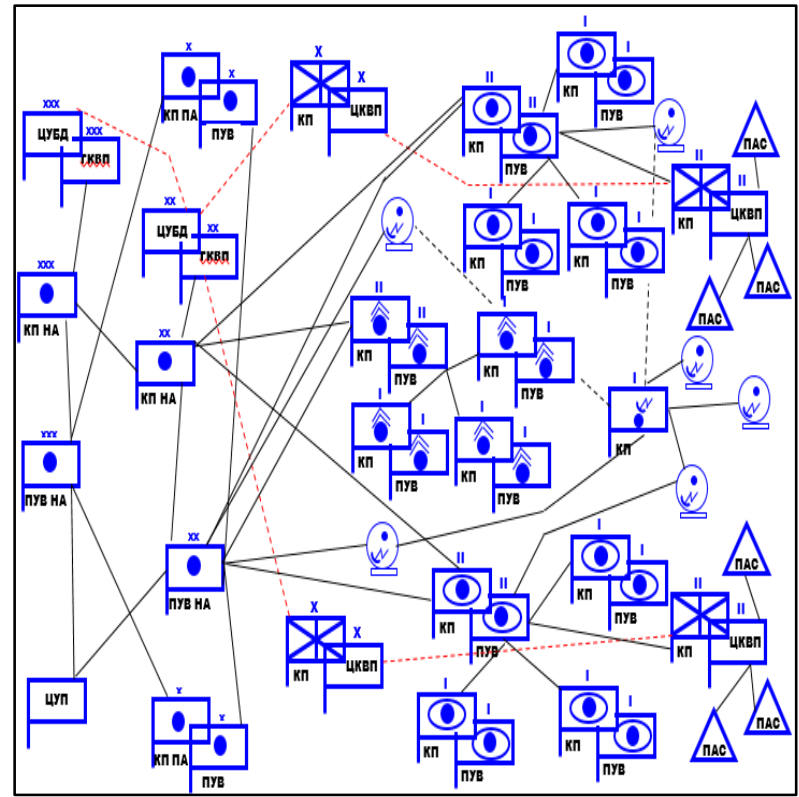

Рис. 1. Схема інформаційної та вогневої взаємодії ACУ AFATDS

зації прийнятих на озброєння, а також впровадження нових систем і засобів автоматизації управління військами і зброєю з використанням останніх досягнень в області інформаційних технологій.

Слід зазначити, що засоби АР є складовою частиною прийнятої на озброєння СВ ЗС Німеччини комп'ютеризованої системи управління вогнем ADLER II (рис. 2) [7].

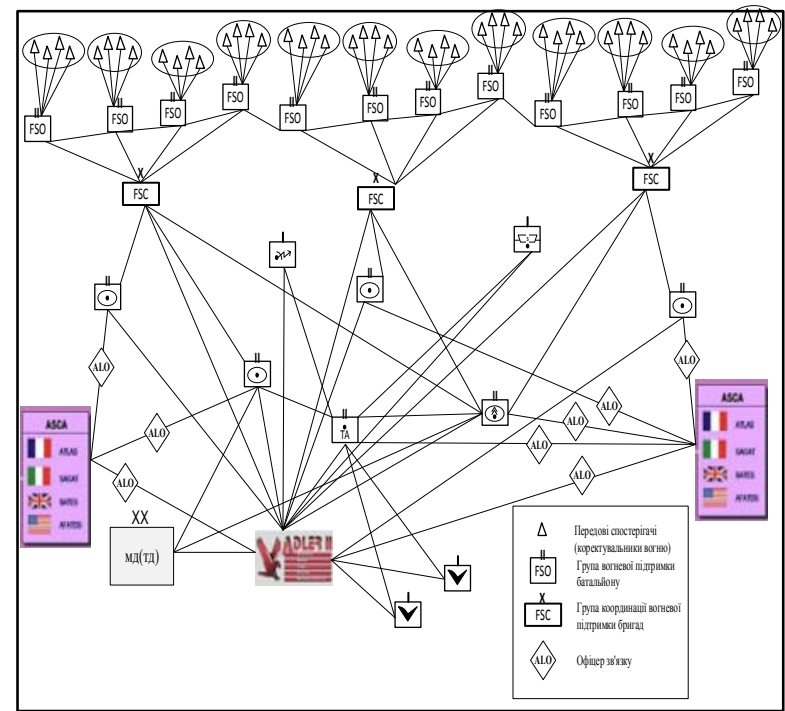

Рис. 2. Схема багаторівневої ACУ ADLER II від штабу дивізії до коректувальників вогню

Застосування зазначеної системи дозволяє скоротити проміжок часу на цикл “виявленняураження”, використовувати засоби АР для корегування вогню 3 мінімальним часом розрахунків і передачі коректур, а також забезпечувати спільне виконання завдань засобами розвідки та засобами ураження під час стрільби керованими снарядами. Широке застосування ПА збройних сил Німеччини 
порівняно нового елемента - безпілотних літальних апаратів (БпЛА) для розвідки цілей і корегування вогню артилерії забезпечує високу ймовірність ураження об'єктів у глибині бойових порядків противника, особливо керованими артилерійськими снарядами (КАС) і високоточними боєприпасами нового покоління [8].

Система ADLER II призначена для управління AP та вогнем ПА дивізії (від артилерійського полку до батареї) і забезпечує вирішення таких основних завдань:

- координацію дій засобів вогневого ураження 3 засобами розвідки, виявлення і супроводження цілей;

- вирішення оптимізаційної задачі щодо розподілення цілей між засобами ураження з урахуванням їх особливостей та бойових можливостей відповідHO;

- управління системами вогневої підтримки бойових дій з'єднань і частин з урахуванням поточної тактичної обстановки або за заздалегідь запланованим сценарієм;

- автоматизоване оброблення розвідувальних відомостей та отриманих даних від частин (підрозділів), доведення наказів і розпоряджень до виконавців;

- управління силами та засобами АР;

- вибір доцільних місць розміщення систем АР;

- топогеодезичну прив'язку елементів бойового порядку підрозділів, пунктів управління (ПУ), засобів АР тощо;

- управління і контроль матеріальнотехнічного забезпечення артилерійських підрозділів [4-5].

Під час планування вогневої підтримки здійснюється обмін інформацією між АСУ органів управління всіх ланок i, за їх результатами, автоматично складається таблиця вогню для декількох варіантів планів на застосування. Після розгляду і затвердження одного з варіантів плану загальновійськовим командиром, органами управління артилерії армійського корпусу (АК) і дивізій розроблені таблиці вогню передаються на ПУ вогневих батарей. На думку західних фахівців [7], слід орієнтуватися на повністю збалансовану побудову угруповання військ, коли кількісно-якісний склад засобів розвідки, управління та ураження підрозділів ПА дозволяють ефективно і в повній мірі виконувати поставлені завдання.

Успіх сучасного бою визначається наявністю єдиного інформаційного простору, коли інформація про об'єкт ураження (ціль), що добувається силами та засобами розвідки, може бути оперативно оброблена й доведена безпосередньо до вогневих підрозділів (засобів ураження ПА).

Ефективне функціонування будь-яких вогневих засобів вимагає не тільки точності ведення вогню, але й своєчасного отримання даних про об'єкти ураження. При цьому розвідувальна інформація про об'єкти повинна бути достатньо повною, що дозволить обрати найбільш важливі 3 них й уражати їх короткими, але потужними вогневими нальотами без додаткового пристрілювання.

ADLER II охоплює всі ланки управління ПА від дивізії до обслуги гармати (міномета, систем залпового вогню, розвідувального засобу тощо). Єдина інформаційна мережа об'єднує засоби розвідки об'єктів (цілей), центри (пункти) управління бойовими діями (вогнем) і вогневі засоби. Це дає можливість не тільки обробляти дані, необхідні для вогневої підтримки, але й управляти режимом викриття та ураження об'єктів (цілей), включаючи оцінювання проміжних результатів стрільби [5; 7].

Об'єднання засобів розвідки (виявлення) і вогневих засобів за допомогою автоматизованої системи оброблення даних цілевказівок і управління артилерійським вогнем ADLER, а також тісний зв'язок між управлінням, розвідкою і вогневими підрозділами дозволяють передавати достовірну розвідувальну інформацію безпосередньо на командні пункти артилерійських підрозділів. В результаті об'єкти противника всіх типів уражуються швидко та 3 високою імовірністю [1].

Таким чином, система ADLER II не тільки обробляє дані, необхідні для вогневої підтримки, але й управляє режимом виявлення та ураження цілей, включаючи оцінювання проміжних результатів стрільби. Завдяки наявності в іiї структурі високопродуктивних електронно-обчислювальних засобів процес ураження визначених цілей оптимізується, що сприяє сполученню інформаційних каналів ADLER II з усіма наявними артилерійськими системами i єдиною комп'ютеризованою системою управління та зв'язку NEROS. При цьому передбачена можливість інформаційної взаємодії, в разі потреби, з артилерійськими органами командування, управління, зв'язку й розвідки інших країн-членів НАТО шляхом використання загальних інтерфейсів.

Комплексування окремих ланок ПА (від передових спостерігачів до начальників артилерії дивізій) в єдину систему дозволяє армійським командирам усіх рівнів мати в підпорядкуванні артилерійські підрозділи, в розпорядженні яких $є$ інформація про противника, свої війська, дружні сили та результати вогневого впливу [7].

Подальший розвиток ПА та ефективність ії бойового застосування найбільше визначаються автоматизацією процесів управління вогнем, включаючи розвідку цілей, оброблення даних і передачу відомостей про об'єкти (цілі) до центрів управління вогнем (ЦУВ), безперервним збором даних про положення і стан своїх вогневих засобів, постановкою їм 
завдань, а також можливістю забезпечення своєчасного виклику і припинення вогню, його корегування та здійснення контролю результатів вогневого впливу. Таким чином, командування СВ ЗС Німеччини приділяе велику увагу створенню сучасної системи управління сухопутними військами у всіх ланках військового управління - від тактичної до оперативної. Послідовно проводяться заходи модернізації з впровадженням сучасних досягнень у галузі управління, зв'язку та інформатизації з урахуванням змін, які вимагає сьогодення, завдань бундесверу та використання національного контингенту військ за межами території держави, а також вимог керівництва Північноатлантичного союзу.

Системний аналіз можливостей сил і засобів розвідки оперативних угруповань військ ЗС України показує, що для забезпечення участі РВіА в операціях (бойових діях) може бути використана розвідувальна інформація, яка отримується від різних родів військ і спеціальних військ Сухопутних військ, видів (родів) військ ЗС України, а також органів розвідки інших складових сектору безпеки і оборони держави. Тому, одним 3 напрямків вдосконалення розвідувального забезпечення застосування частин та підрозділів РВіА слід вважати організацію отримання розвідувальної інформації про об'єкти противника, призначені для вогневого ураження, від усіх органів управління розвідкою (засобів розвідки), що діють у зоні відповідальності (смузі оборони, наступу) угруповання військ, також від органів розвідки вищого рівня та по взаємодії від інших складових сектору безпеки держави.

Командир (начальник) артилерійського підрозділу зобов'язаний організувати отримання від сил і засобів АР необхідну розвідувальну інформацію про об'єкти вогневого ураження противника. Слід зазначити, що розвідка ведеться засобами оптичної, звукової, радіолокаційної, радіоелектронної та повітряної розвідки (БПЛА), що входять до складу загальновійськових частин та підрозділів, а також артилерійських частин і підрозділів. Отже, іншим напрямком підвищення ефективності розвідки слід вважати вдосконалення організації системи розвідки (в тому числі - артилерійської).

Розвідувальні завдання щодо викриття об'єктів (цілей) противника, призначених для вогневого ураження РВіА, можуть виконуватися силами і засобами розвідки старшого начальника, а також розвідкою взаємодіючих з'єднань та частин. Крім того, до командирів повинна доводитись розвідувальна інформація, отримана засобами повітряної розвідки Повітряних Сил та підрозділами Сил спеціальних операцій ЗС України, іншими розвідувальними органами формувань сектору безпеки і оборони держави. Отже, для отримання максимально повної розвідувальної інформації про об'єкти ураження виникає нагальна потреба в організації взаємодії та узгодженні зусиль сил і засобів розвідки різних родів військ Сухопутних військ та різних видів ЗС України, в тому числі розвідувальних підрозділів інших військових формувань та правоохоронних органів держави. Тобто, для ефективного вогневого ураження військ (сил) та об'єктів противника необхідно впроваджувати комплексний підхід до організації розвідки в інтересах РВіА в операціях (бойових діях). В умовах створення єдиного розвідувального інформаційного простору важливого значення набуває можливість технічного сполучення комплексів (засобів) розвідки, у тому числі і артилерійської, з комплексами (засобами) автоматизації процесів організації та управління розвідкою.

Важливим напрямком розвитку бойових спроможностей є створення розвідувально-вогневої системи РВіА як складової частини розвідувальноударної системи загальновійськового формування. При цьому необхідно вирішити проблеми ефективності всіх видів оперативної і тактичної розвідки $з$ обов'язковим урахуванням вимог до актуальності, повноти і достовірності розвідувальної інформації про об'єкти вогневого ураження противника.

Таким чином, для побудови розвідувальновогневої системи РВіА потрібне створення нових (модернізація існуючих) засобів АР, здатних в реальному масштабі часу забезпечити командирів (начальників) достовірними розвідувальними даними про об'єкти (цілі) ураження для прийняття своєчасних та обгрунтованих рішень щодо їх ураження.

Умовно завдання розвідувально-вогневої системи РВіА можна розділити на два типи: ураження нерухомих об'єктів (цілей) і ураження колон та високоманеврених об'єктів (цілей). При ураженні нерухомих об'єктів допускається затримка за часом прийняття рішення на застосування вогневих засобів. Тобто можливе отримання та накопичення розвідувальних даних про об'єкти (цілі) від органів управління оперативної та тактичної розвідки (при чіткій організації взаємодії засобів розвідки з засобами вогневого ураження).

Для розвідки й ураження колон та високоманеврених об'єктів (цілей) необхідно мати штатні сили і засоби АР, що дозволить реалізувати принцип “розвідав - уразив”. Безумовно, в будь-якому випадку сили та засоби розвідки повинні забезпечити виконання вогневих завдань. 3 цього випливає, що добування розвідувальної інформації про об'єкти (цілі) противника, визначені для ураження $\mathrm{PBiA,} \mathrm{має} \mathrm{здій-}$ снюватися двома каналами (напрямками): першим органами (засобами) військової розвідки, здатними забезпечувати функціонування розвідувальновогневої системи РВіА, а другим - силами АР загальновійськових та артилерійських військових частин та підрозділів. 
Таким чином, підвищити ефективність розвідки, яка забезпечує застосування РВіА у сучасних операціях, можна шляхом вдосконалення органів та засобів військової розвідки (у першу чергу тактичної і оперативної) 3 метою приведення їх можливостей у відповідність до встановлених вимог щодо визначення місця розташування об'єктів (цілей), а також за рахунок скоординованого (збалансованого) розвитку технічних засобів АР для організації взаємодії з засобами вогневого ураження розвідувальновогневої системи.

Що стосується першого напрямку, завдання полягає в забезпеченні розвитку технічних засобів військової розвідки загальновійськових частин і підрозділів шляхом розроблення науковообгрунтованих вимог до базової структури системи розвідки та технічних засобів (комплексів) розвідки.

Щодо другого напрямку, необхідно підкреслити наступне. Проведені дослідження показують [9], що основними першочерговими об'єктами (цілями) при ураженні яких необхідно керуватися принципом “розвідав - вразив”, є: пускові установки оперативно-тактичних ракет на стартових позиціях (у районі зосередження, на марші); артилерійські батареї; взводи РСЗВ; мінометні взводи на вогневій позиції (у районі зосередження, на марші); радіолокаційні станції АР; пункти управління вогнем артилерійських дивізіонів; пункти управління вогнем артилерійських батарей, засоби РЕБ.

3 огляду на характер даних об'єктів (цілей) та їх розвідувальні ознаки, можна виділити види АР, а також засоби, які повинні бути у розпорядженні командирів підрозділів.

Отже, щоб забезпечити необхідний рівень ефективності АР, необхідно вирішити два взаємопов'язані завдання: підвищити тактико-технічні характеристики розвідувальних систем (комплексів), а також покращити функціональні можливості засобів і способів оброблення розвідувальної інформації.

Слід зазначити, що принциповими відмінностями перспективної номенклатури засобів розвідки (у тому числі артилерійської) від існуючої є:

- значне покращення їх можливостей щодо глибини ведення розвідки і оперативності функціонування за рахунок роботизації та автоматизації процесів викриття (виявлення, орієнтування, розпізнавання, ідентифікації) об'єктів противника, визначення їх координат і надання розвідувальних даних;

- оснащення сучасними засобами розвідки, які використовують різні фізичні принципи дії, а також ї комплексування та інтегрування в єдину систему;

- введення у склад підрозділів АР комплексів повітряної розвідки з БпЛА, які повинні забезпечувати визначення характеру та координат об'єктів (цілей) ураження з необхідною точністю.

\section{Висновки}

Таким чином, в статті розкриті сутність розвідувального забезпечення бойового застосування PBiА та визначені напрямки вдосконалення системи розвідувального забезпечення з урахуванням подальшого розвитку бойових можливостей засобів вогневого ураження РВiА

Результати досліджень та отриманий досвід застосування військ показують, що основні напрямки діяльності у вирішенні зазначених завдань необхідно зосередити в організаційній, технічній і науковій cферах.

В організаційній: приведення організаційноштатної структури та методів роботи органів управління розвідкою (у тому числі артилерійською) загальновійськових формувань у відповідність до оптимізованого складу (структури) військових частин і підрозділів розвідки, що передбачає наявність у кожному загальновійськовому формуванні комплекту сил і засобів для ведення розвідки об'єктів (цілей) противника з метою скорочення часу на їх ураження вогневими засобами.

У технічній: модернізація існуючих технічних засобів видів розвідки (у тому числі артилерійської), потенційно здатних вести розвідку відповідно до встановлених вимог щодо визначення місць розташування об'єктів (цілей) противника; розроблення i прийняття на озброєння нових засобів розвідки, робота яких заснована на використанні сучасних сенсорів та алгоритмів оброблення отримуваної інформації та дозволяє впроваджувати технології комплексування й інтегрування;

комплексна автоматизація організації та управління розвідкою з метою своєчасного забезпечення РВіА необхідними розвідувальними даними про об'єкти (цілі) для їх вогневого ураження.

У науковій області: проведення досліджень 3 пошуку нових способів побудови технічних засобів розвідки на основі використання нетрадиційних фізичних принципів фіксування демаскуючих ознак об'єктів (цілей) противника.

Не можна залишити без уваги питання збору, оброблення і доведення розвідувальної інформації в рамках розвідувально-вогневої системи РВіА. Так, виконання завдань щодо негайного ураження мобільних об'єктів (цілей) противника вимагає, щоб цикл розвідки, прийняття рішення і підготовки до виконання вогневого завдання не перевищував половини мінімальних термінів перебування об'єктів на місці [9]. Отже, процес збору, оброблення і доведення розвідувальної інформації до виконавців повинен бути автоматизований.

Необхідно зазначити, що реалізація запропонованих підходів до розвитку сил (засобів) розвідки, включених у розвідувально-вогневу систему $\mathrm{PBiA,}$ 
дозволить ефективно вирішувати завдання бойового застосування РВіА у сучасних операціях в якості основної складової розвідувально-вогневої (розвідувально-ударної) системи загальновійськового (міжвидового оперативно-тактичного) угруповання. При цьому слід підкреслити, що фактор часу визначає успіх в операції (бойових діях). Тому розвідку в цих умовах слід розглядати як складову частину збройної боротьби (вогневого ураження противника), а до сил і засобів розвідки (у тому числі артилерійської) необхідно підходити як до складової частини бойового потенціалу частин і підрозділів РВіА.

\section{Список літератури}

1. Особливості та принципи побудови мережецентричної системи управління угруповання військ (сил) / О.М. Загорка, В.В. Коваль, В.В. Тюрін, В.Г. Малюга, І.О. Загорка // Збірник наукових праць Харківського національного університету Повітряних Сил. - 2016. - № 3(48), - С. 7-11.

2. Вплив засобів автоматизації управління підрозділами і вогнем артилерії на ефективність ії застосування / П.П. Ткачук, Ю.І. Бударецький, Ю.В. Щавінський, В.В. Прокопенко // Військово-технічний збірник. - 2015. - № 12. C. $75-82$.

3. Ткачук П.П. Аналітичний огляд світових тенденцій розвитку систем цілевказування в артилерії / П.П. Ткачук, В.В. Яковенко, О.В. Корольова / Військово-технічний збірник. - 2012. - № 6. - С. 150-155. https://doi.org/10.33577/2312-4458.6.2012.150-155.

4. Вишневський Ю.В. Щодо перспектив створення автоматизованої системи збору та обробки розвідувальних відомостей / Ю.В. Вишневський // Збірник тез доповідей науково-технічної конференції “Перспективи розвитку ракетних військ і артилерії Сухопутних військ”. - Львів: Академія Сухопутних військ. - 2014. - С. 40-42.

5. Сергієнко Р.В. Досвід застосування засобів артилерійської розвідки у контрбатарейній боротьбі / Р.В. Сергієнко, О.А. Дідіченко // Збірник тез доповідей науково-технічної конференції “Перспективи розвитку ракетних військ і артилерії Сухопутних військ”. - Львів: Академія Сухопутних військ. - 2014. - С. 101-103.

6. Репіло Ю.С. Погляди військових фахівців провідних країн світу на концепцію вогневого ураження противника в операціях / Репіло Ю.С.: Матеріали науково-практичного семінару кафедри ракетних військ і артилерії. - К.: НУОУ. 2014. - С. $30-40$.

7. Офіційний сайт ZVO.SU. Нові автоматизовані системи управління для армії США. Сухопутні війська. Режим доступу: http://www.zvo.su/suhoputnye-voyska/novye-asu-dlya-armii-ssha.html.

8. Офіційний сайт ZVO.SU. Автоматизація управління сухопутними військами в країнах НАTO. Сухопутні війська. - Режим доступу: http://www.zvo.su/suhoputnye-voyska/avtomatizaciya-upravleniya-suhoputnymi-voyskami-v-stranahnato.html.

9. Офіційний сайт RAYTHEON.COM. Advanced Field Artillery Tactical Data System (AFATDS). - Режим доступу: https://www.raytheon.com/capabilities/products/afatds.

10. Дмитриев В.О. Совершенствование средств разведки и обеспечения стрельбы полевой артиллерии сухопутных войск США / В.О. Дмитриев // Зарубежное военное обозрение. - 2016. - № 8. - С. 45-51.

11. Крупнов A.В. Автоматизированная система управления огнем полевой артиллерии ADLER II сухопутных сил Германии / А.В. Крупнов // Зарубежное военное обозрение. - 2010. - № 10. - С. 45-47.

12. До питання застосування розвідувально-ударних і розвідувально-вогневих комплексів у мережецентричній війні / О.М. Загорка, В.О. Колесников, В.В. Коваль, І.О. Загорка // Наука і техніка Повітряних Сил Збройних Сил України. -2012. - № 3(9). - C. 8-13.

13. Army Techniques Publication No. 3-09.24. Techniques for the Fires Brigade [Електронний ресурс]. - Washington: CreateSpace Independent Publishing Platform, 2012. - 186 p. - Режим доступу: https://www.amazon.com/TechniquesPublication-3-09-24-3-09-22-November/dp/1481200356.

14. Пащук Ю.М. Система ISTAR - критичний елемент досягнення інформаційної переваги у сучасних війнах та конфліктах / Ю.М. Пащук, Ю.П. Сальник // Збірник наукових праць Харківського національного університету Повітряних Сил. - 2012. - № 3(32). - С. 21-30.

15. Бєляєв М.І. Моніторинг стану самохідної артилерії сухопутних військ Збройних Сил України та визначення напрямків ії розвитку / М.І. Бєляєв, О.М Толмачов // Військово-технічний збірник. - 2015. - № 3(43). - C. 11-15.

16. Field Manual 2-0. Joint Intelligence. - Washington: Headquarters. Department of the Army Washington, 2018. - P. V1-V8. - Режим доступу: https://www.jcs.mil/Portals/36/Documents/Doctrine/pubs/jp2_0.pdf.

17. Field Manual 3-09. Field Artillery Operations and Fire Support. Section II. - Washington: Headquarters, Department of the Army Washington, 2014. - P. 4-12. $\quad$ P https://armypubs.army.mil/epubs/DR_pubs/DR_a/pdf/web/fm3_09.pdf.

\section{References}

1. Zahorka, O.M., Koval, V.V., Tyurin, V.V., Malyuha, V.H. and Zahorka, I.O. (2016), “Osoblyvosti ta pryntsypy pobudovy merezhetsentrychnoi systemy upravlinnia uhrupovannia viisk (syl)" [Features and principles of network-centric system construction control grouping of troops (forces)], Scientific Works of Kharkiv National Air Force University, No. 3(48), pp. 7-11.

2. Tkachuk, P.P., Budaretsky, Yu.I., Shchavinsky, Yu.V. and Prokopenko, V.V. (2015), "Vplyv zasobiv avtomatyzatsii upravlinnia pidrozdilamy i vohnem artylerii na efektyvnist yii zastosuvannia" [The Influence of Automation Controls on Units and Fire of Artillery on the Efficiency of Its Use], Military Technical Collection, No. 12, pp. 75-82.

3. Tkachuk, P.P., Yakovenko, V.V. and Koroleva, O.V. (2012), "Analitychnyi ohliad svitovykh tendentsii rozvytku system tsilevkazuvannia v artylerii" [Analytical review of the world tendencies of development of targeting systems in artillery], Military and Technical Collection, No. 6, pp. 150-155, https://doi.org/10.33577/2312-4458.6.2012.150-155.

4. Vishnevsky, Yu.V. (2014), "Shchodo perspektyv stvorennia avtomatyzovanoi systemy zboru ta obrobky rozviduvalnykh vidomostei" [The prospects for creating an automated intelligence collection and processing system], Proceedings of the 
Scientific and Technical Conference "Prospects for the Development of the Rocket Industry and Land Forces", 2014, Lviv, Ukraine, pp. 40-42.

5. Sergienko, R.V. and Didichenko, O.A. (2014). "Dosvid zastosuvannia zasobiv artyleriiskoi rozvidky u kontrbatareinii borotbi" [Experience in using artillery reconnaissance in counter-combat]. Proceedings of the Scientific and Technical Conference "Prospects for the Development of the Rocket Industry and Land Forces", 2014, Lviv, Ukraine, pp. 101-103.

6. Repilo, Yu.E. (2014), "Dosvid zastosuvannia zasobiv artyleriiskoi rozvidky u kontrbatareinii borotbi" [The views of military experts of the leading countries of the world on the concept of enemy fire in operations], Materials of the ScientificPractical Seminar of the Missile Troops and Artillery Department, Kyiv, pp. 30-40.

7. The official site of ZVO.SU (2019), "Novi avtomatyzovani systemy upravlinnya dlya armiyi SShA. Suxoputni vijska" [New Automated Control Systems for the US Army. Army], available at: www.zvo.su/suhoputnye-voyska/novye-asu-dlya-armiissha.html

8. The official site of ZVO.SU (2019), "Avtomatyzaciya upravlinnya suxoputnymy vijskamy v krayinax NATO. Suxoputni vijska" [Automation of ground forces management in NATO countries. Army], available at: www.zvo.su/suhoputnyevoyska/avtomatizaciya-upravleniya-suhoputnymi-voyskami-v-stranah-nato.html.

9. The official site of RAYTHEON.COM (2016), Advanced Field Artillery Tactical Data System (AFATDS), available at: www.raytheon.com/capabilities/products/afatds.

10. Dmitriev, V.O. (2016), "Sovershenstvovanye sredstv razvedky y obespechenyia strelby polevoi artylleryy sukhoputnykh voisk SShA" [Improving the means of reconnaissance and providing firing of field artillery of the US Army], Foreign Military Review, No. 8, pp. 45-51.

11. Krupnov, A.V. (2010), “Avtomatyzyrovannaia systema upravlenyia ohnem polevoi artylleryy ADLER II sukhoputnыkh syl Hermanyy" [Automated fire control system for field artillery ADLER II of the German ground forces], Foreign Military Review, No. 10, pp. 45-47.

12. Zahorka, O.M., Kolesnykov, V.O., Koval, V.V. and Zahorka, I.O. (2012), "Do pytannia zastosuvannia rozviduvalnoudarnykh i rozviduvalno-vohnevykh kompleksiv u merezhetsentrychnii viini" [On the Use of Reconnaissance-Shock and Reconnaissance-Fire Complexes in Network-Centric Warfare], Science and Technology of the Air Force of Ukraine, No. 3(9), pp. 8-13.

13. Army Techniques Publication No. 3-09.24. (2012), Techniques for the Fires Brigade, CreateSpace Independent Publishing Platform, Washington, 186 p., available at: www.amazon.com/Techniques-Publication-3-09-24-3-09-22November/dp/1481200356.

14. Pashchuk, Yu.M. and Salnyk, Yu.P. (2012), "Systema ISTAR - krytychnyi element dosiahnennia informatsiinoi perevahy u suchasnykh viinakh ta konfliktakh" [ISTAR is a Critical Element for Achieving Information Excellence in Modern Wars and Conflicts], Scientific Works of Kharkiv National Air Force University, No. 3(32), pp. 21-30.

15. Bipadav, M.I. and Tolmachev, O.M. (2015), "Monitorynh stanu samokhidnoi artylerii sukhoputnykh viisk zbroinykh syl Ukrainy ta vyznachennia napriamkiv yii rozvytku" [Monitoring of the existing self-propelled artillery of the dry military forces, the mature forces of Ukraine, supports its development], Military Technical Collection, No. 3 (43), pp. 11-15.

16. Field manual 2-0 (2018), Joint Intelligence. Headquarters. Department of the Army Washington, Washington, pp. V-1 - V-8, available at: www.jcs.mil/Portals/36/Documents/Doctrine/pubs/jp2_0.pdf.

17. Field manual 3-09 (2014), Field Artillery Operations and Fire Support. Section II. Headquarters. Department of the Army Washington, pp. 4.1-4.12, available at: www.armypubs.army.mil/epubs/DR_pubs/DR_a/pdf/web/fm3_09.pdf.

\section{Відомості про авторів:}

\section{Шуляков Сергій Олексійович}

начальник науково-дослідного відділу науково-дослідного центру ракетних військ і артилерії, Суми, Україна https://orcid.org/0000-0001-8496-1308

\section{Бзот Володимир Броніславович}

кандидат технічних наук старший науковий співробітник начальник науково-дослідної лабораторії Харківського національного університету

Повітряних Сил ім. І. Кожедуба,

Харків, Україна

https://orcid.org/0000-0001-5804-1161

\section{Жилін Євген Ігорович}

кандидат технічних наук старший науковий співробітник провідний науковий співробітник

Харківського національного

університету Повітряних Сил ім. І. Кожедуба,

Харків, Україна

https://orcid.org/0000-0002-2076-6463

\section{Information about the authors:}

\section{Serhii Shuliakov}

Chief of Scientific Research Department

of Research Center for Missile Force sand Artillery,

Sumy, Ukraine

https://orcid.org/0000-0001-8496-1308

\section{Volodymyr Bzot}

Candidate of Technical Sciences

Senior Research

Chief of Research Laboratory

of Ivan Kozhedub Kharkiv

National Air Force University,

Kharkiv, Ukraine

https://orcid.org/0000-0001-5804-1161

\section{Yevhenii Zhylin}

Candidate of Technical Sciences Senior Research

Lead Research

of Ivan Kozhedub Kharkiv

National Air Force University,

Kharkiv, Ukraine

https://orcid.org/0000-0002-2076-6463 
Шигімага Наталія Вікторівна

молодший науковий співробітник

Харківського національного університету

Повітряних Сил ім. І. Кожедуба,

Харків, Україна

https://orcid.org/0000-0002-6326-0008

\section{Артеменко Артем Анатолійович}

старший науковий співробітник

Харківського національного університету

Повітряних Сил ім. І. Кожедуба,

Харків, Україна

https://orcid.org/0000-0002-9462-1566

\author{
Natalia Shigimaga \\ Junior Research \\ of Ivan Kozhedub Kharkiv \\ National Air Force University, \\ Kharkiv, Ukraine \\ https://orcid.org/0000-0002-6326-0008 \\ Artem Artemenko \\ Senior Research \\ of Ivan Kozhedub Kharkiv \\ National Air Force University, \\ Kharkiv, Ukraine \\ https://orcid.org/0000-0002-9462-1566
}

\title{
ПУТИ СОВЕРШЕНСТВОВАНИЯ РАЗВЕДЫВАТЕЛЬНОГО ОБЕСПЕЧЕНИЯ БОЕВОГО ПРИМЕНЕНИЯ РАКЕТНЫХ ВОЙСК И АРТИЛЛЕРИИ
}

\author{
С.А. Шуляков, В.Б. Бзот, Е.И. Жилин, Н.В. Шигимага, А.А. Артеменко
}

В статье рассмотрена система разведки, которая является составляющей информационного обеспечения функиионирования автоматизированной системы управления (АСУ) подразделений ракетных войск и артиллерии, а также, опыт управления средствами огневого поражения и средствами разведки. Проведен анализ их взаимодействия, особенностей АСУ полевой артиллерии Advanced Field Artillery Tactical Data System (AFATDS), которая является составляющей АСУ армейского корпуса США, а также многоуровневой АСУ ADLER II сухопутных войск вооруженных сил Германии. АСУ полевой артиллерии $A F A T D S$ - многочелевая тактическая информационная система полевой артиллерии на подвижных средствах. Она обеспечивает автоматизированное принятие решений для функииональной подсистемь огневой поддержки, как сухопутных войск и морской пехоты, так и объединенных оперативных формирований, и объединенных родов войск. В статье рассмотрен весь сектор возможностей этой автоматизированной системы боевого управления. АСУ полевой артиллерии ADLER II - охватьввает все звенья управления полевой артиллерией от дивизии до расчета орудия (миномета, РСЗО, разведывательного средства). Единая информачионная сеть объединяет средства обнаружения целей, центры (пункты) управления боевыми действиями (огнем) и огневые средства. Это дает возможность не только обрабатывать данные, необходимые для огневой поддержки, но и управлять режимом обнаружения и поражения иелей, включая оценку промежуточных результатов стрельбы. ADLER II интегруется со всеми аналогичными автоматизованными системами управления вооруженых сил стран HATO: AFATDS (CША), ВATES (Великобритания) и ATLAS (Франиия). Интегрированные системы разведки, наблюдения, определения иелей и их поражения рассматривается военными специалистами ведущих, в военном отношении, стран мира как критический элемент для достижения информачионного превосходства над противником. Определено, что возможным путем усовериенствования системы разведывательного обеспечения ракетных войск и артиллерии Сухопутных войск Вооруженных Сил Украины является организация получения разведывательной информации про объекты противника от всех органов военного управления тактической и оперативной разведки (средств разведки), которые действуют в зоне ответственности (полосе обороны, наступления) группировки войск.

Ключевые слова: разведка, средства огневого поражения, разведывательно-огневая система ракетных войск и артиллерии, автоматизированная система управления, система боевого управления, разведывательно-огневой комплекс.

\section{WAYS TO IMPROVE THE INTELLIGENCE SUPPORT OF ROCKET TROOPS AND ARTILLERY COMBAT USE}

\author{
S. Shuliakov, V. Bzot, Ye. Zhylin, N. Shigimaga, A. Artemenko
}

In the article consider the reconnaissance system, which is a component of the information support of the rocket troops and artillery units automated control system (ACS), as well as the experience in managing fire weapons and reconnaissance equipment. An analysis of the interaction, the features of the Advanced Artillery Tactical Data System (AFATDS) field artillery automated control system, which is part of the United States Army automatic control system, as well as the multi-level ADLER II automatic control system of the German Land forces, is carried out. AFATS field artillery ACS is a multi-purpose tactical information system for field artillery on mobile vehicles. It provides automated decision-making for the functional subsystem of fire support, both of the Army and Marine Corps, as well as the combined and joined operational formations. The article considers capabilities of this automated combat control system as a whole. ACS of field artillery ADLER II-covers all the links of control of field artillery from the division and down to the crew (mortars, MLRS, reconnaissance equipment). The unified information network unites means of target detection, centers (points) of military operations (fire) control and fire means. This makes it possible not only to process the data necessary for fire support, but also to control the detection and destruction of targets, including the assessment of intermediate results of firing. ADLER II integrates with all similar automated control systems of the armed forces of NATO countries: AFATDS (USA), BATES (Great Britain) and ATLAS (France). Integrated reconnaissance, surveillance, targeting and defeat systems are considered by military experts of leading militarily, countries of the world as a critical element for achieving information superiority over the enemy. It was determined that a possible way of improving the intelligence system of rocket troops and artillery of the Land Forces of the Armed Forces of Ukraine is to organize the collection of intelligence information about enemy targets from all military tactical and operational intelligence control units (reconnaissance assets) that operate in the area of responsibility of troops.

Keywords: reconnaissance, means of fire destruction, reconnaissance and fire system of rocket troops and artillery, automated control system, combat control system, reconnaissance and fire complex. 